\title{
Welcoming the transposition of the European Tobacco Products Directive
}

\author{
Froncisco Rodriguez Lozono ${ }^{1}$
}

$\mathrm{T}$ oday, the 20th of May 2016, the new Tobacco Products Directive enters into force. European Union Member States finally have clear guidance and requirements on electronic cigarettes, traceability, the use of additives in tobacco products, standardised packaging, etc. ${ }^{1}$ Electronic cigarettes are now regulated under the directive, improving their reliability and avoiding their unrestrained promotion. Traceability provisions in the new Directive will allow to effectively fight smuggling of tobacco products. The TPD further contains a specific ban on almost all flavouring: tobacco will taste of tobacco and not strawberry, chocolate or vanilla. Regarding packaging, with the new Directive we will see an improvement in tobacco control through greater information on the health effects and larger graphic warnings with clearer messages. Some countries such as Ireland, the UK and France have gone beyond the minimum stipulation in the new TPD and have opted for plain packaging measures; others have announced that they are following suit. . $^{2-6}$ I sincerely believe that this is a day to congratulate ourselves. Today, public health has prevailed over the tobacco industry's economic interests. The measures provided in the TPD are proven to reduce and will reduce further the smoking prevalence in Europe, especially among our youth. This is a victorious step against a deadly business that keeps users addicted. To get to where we are now, numerous discussions and debates have taken place, first of all within the European Parliament, but also between the Parliament, the Commission and the Council. Although we have not achieved everything initially intended - menthol flavour will still be allowed until 2020 and plain packaging will for now only be adopted in a few Member States - the Directive marks a victory in the battle for health over the tobacco industry. Lately, the European Court of Justice has supported the European Commission in its response to challenges from the tobacco industry against the Directive. ${ }^{7}$

From now on, the situation is unstoppable and we, the public health community, are unstoppable. In 2002, Canada and Brazil adopted graphic warnings on cigarette packs. It took three years for a third country, Singapore, to follow suit. Ten years on, so many more countries have joined the movement. ${ }^{8}$ Similarly, in 2012 Australia was the first to adopt plain packaging and it took three years before other countries decided to follow in its footsteps. ${ }^{9,10}$ Like the adoption of pictorial warnings, this trend can only grow and will not recede. On behalf of ENSP, I would like to congratulate and thank the European Commission, the Parliament and all European governments, but above all, the citizens of the European Union. This historic moment will have a large impact on health, culture and the lives of millions of people and for the years to come.
AFFILIATION

1 European Network for Smoking and Tobacco Prevention (ENSP) CORRESPONDENCE TO Francisco Rodriguez Lozano

European Network for Smoking and Tobacco Prevention, Chaussee d'Ixelles 144, B-1050 Brussels, Belgium 


\section{Editorial}

\section{REFERENCES}

1 Directive of the European Union on the approximation of the laws, regulations and administrative provisions of the Member States concerning the manufacture, presentation and sale of tobacco and related products and repealing Directive 2001/37/EC. Available from http://ec.europa.eu/health/tobacco/docs/dir_201440_en.pdf

2 House of the Oireatchas, Public Health (Standardised Packaging of Tobacco) Bill 2014, Bill Number 54 of 2014 [Seanad]. Available from: http://www.oireachtas.ie/viewdoc.asp?DocID=26331\&\&CatI D=59

3 Legislation.gov.uk, 2015 No. 829 PUBLIC HEALTH The Standardised Packaging of Tobacco Products Regulations 2015. Available from: http://www.legislation.gov.uk/uksi/2015/829/pdfs/ uksi_20150829_en.pdf

4 Legifrance, LOI n $^{\circ}$ 2016-41 du 26 janvier 2016 de modernisation de notre système de santé (1), Article 27. Available from: https://www. legifrance.gouv.fr/affichTexte.do;jsessionid=F689F8B21B0A40D85 4AD952E5555E270.t

5 Hungary Today, Hungary considering introduction of Australianstyle uniform packaging for tobacco products, 2015. Available from: http://hungarytoday.hu/news/hungary-considering-introductionaustralian-style-uniform-packaging-tobacco-products-12763

6 Legislation. Maggie De Block's website, Plan anti-tabac avec interdiction de fumer en voiture en présence d'enfants et augmentation des accises, 2016. Available from: http:// www.deblock.belgium. be/fr/plan-anti-tabac-avec-interdiction-defumer-en-voiture-en-pr\%C3\%A9sence-d\%E2\%80\%99enfants-etaugmentation-des

7 Court of Justice of the European Union Press release No 48/16 Luxembourg, 4 May 2016. Available from: http://curia.europa.eu/jcms/upload/docs/application/pdf/2016- 05/ cp160048en.pdf

8 Fong G, Hammond D, Hitchman S. The impact of pictures on the effectiveness of tobacco warnings. Bulletin of the World Health Organization 2009;87:640-643 doi: 10.2471/BLT.09.069575

9 Diethelm P, Farley T. Refuting tobacco-industry funded research: empirical data shows decline in smoking prevalence following introduction of plain packaging in Australia. Tob. Prev. Cessation 2015;1(November):6 doi: http://www.dx.doi.org/10.18332/tpc/60650

10 Canadian Cancer Society. Plain Packaging - International Overview. Available from: https://www.cancer.ca/ /media/cancer.ca/CW/for\% 20media/Media\%20releases/2016/plain-packaging-overview--

-2016-01-11.pdf?la=en 